\title{
RE-EVALUATION OF A GAS STORAGE RESERVOIR IN THE MOESIAN PLATFORM USING A MULTI-CRITERIA INTEGRATED ANALYSIS
}

\author{
Dragos Cristea ${ }^{1}$
}

\author{
${ }^{1}$ Petroleum-Gas University of Ploiesti, Romania \\ e-mail: dragos.cristea@upg-ploiesti.ro
}

DOI: 10.51865/JPGT.2021.02.05

\begin{abstract}
An integrated approach was used to analyse the quality of a Miocene reservoir in the Moesian Platform, Romania. While this paper goes through all the main components of an integrated study (seismic, petrophysics, reservoir engineering), the main focus was on well data.

This research focused on modelling the structure using mainly well data. The reservoir is associated with an alluvial cone structure and a canal system NNW-SSE, with the lithological traps in the southern part [1].

The reservoir pressure and the behaviour during production indicates a gas expansion is the main displacement mechanism, alongside a low influx of water.

The results of this paper show that the performance of the reservoir is influenced not only by the available energy (the elastic gas expansion and a low influx of water), but also by the spatial distribution of different facies in relation to the well locations.

Gas production started in 1962 and continues to this day. However, the Miocene reservoir was chosen for gas storage (UGS-Underground Gas Storage) due to its relatively large thickness, good porosity and large surface area [2].

The purpose of a reservoir characterisation is to incorporate existing data from petrophysics, geophysics, geological and reservoir engineering, so that the results obtained by the multidisciplinary team can be used to create a reservoir model which will improve economic results.
\end{abstract}

Keywords: seismic data, well data, reservoir, geophysics, geology

\section{INTRODUCTION}

Using an integrated approach to evaluate the quality of the reservoir and the potential of production is getting more and more important in petroleum geology.

This integrated approach was used to analyse the quality of an old Miocene reservoir in the Moesian Platform, Romania. While this paper goes through all the main components of an integrated study (seismic, petrophysics, reservoir engineering), the main focus was on well data. 
The purpose of a reservoir characterisation is to incorporate existing data from petrophysics, geophysics, geological and reservoir engineering, so that the results obtained by the multidisciplinary team can be used to create a reservoir model which will improve economic results.

The methodology and the results for each phase are summarized in the following sections: seismic, petrophysics and reservoir engineering.

\section{SEISMIC}

The 3D seismic study for the analysed structure was acquired and interpretated interpreted by a private company, and reinterpreted by us, with the following results:

- The structure consists of an unfaulted hemianticline dipping North and with purely stratigraphic traps in the SW.

- Eight horizons were interpreted; they present a good correlation in Neogene, Mesozoic and Palaeozoic deposits.

- The reservoir (sandy Miocene) is associated with an alluvial cone structure and a canal system NNW-SSE, with the lithological traps in the southern part.

- The canal system represents the location for the active aquifer and can be the preferred migration path for the water into the reservoir. The porosity and permeability are higher in the canals, which is in accordance with the water migration, the gas/water contact migrated $600 \mathrm{~m}$ to the South [3].

\section{GEOLOGY AND PETROPHYSICS}

The structure is located in the northern part of the Moesian Platform, South of the Peri Carpathian fault and West of the Târgu Fierbinţi-Belciugatele fault.

In the study area well penetrated sediments from Cretaceous to Quaternary, however the Paleogene and lower Miocene deposits are missing due to the uplift of the Cretaceous Basement and its partial erosion forming Preneogene Unconformity (PNU) and its paleoshape combined with the undepositional period from Cretaceous up to Upper Miocene [4, 5].

The interpretation of the 3D seismic data showed an argillic alteration of the Miocene reservoir, which was caused by lithofacial changes, resulting in a stratiform trap which is lithologically screened.

The productive formation, Meotian, has an average thickness of $150 \mathrm{~m}$, but it only produces from $30 \mathrm{~m} \mathrm{[6]}$. The main data for correlation and for the determination of the petrophysical properties was taken from geophysical data from 62 wells from the study area.

The main petrophysical properties were determined: shale volume, effective porosity, water saturation and permeability.

Unfortunately, no core data were available for this study, and only the lithological core descriptions used as a reference to compare the interpreted geology from well logs.

The results of the petrophysical analysis were used to create a series of structural maps, thickness maps, net-to-gross maps, porosities maps etc. 
The specific objectives of petrophysical analysis include:

- Editing and normalizing the raw data (Figure 1).

- Calculating and calibrating the shale volume

- Calculating the effective porosity

- Calculating and calibrating the water saturation

- Calculating the permeability

- Identifying the electrofacies

- Identifying the limits of the productive zones (cut-offs și net-pay) [7, 8].

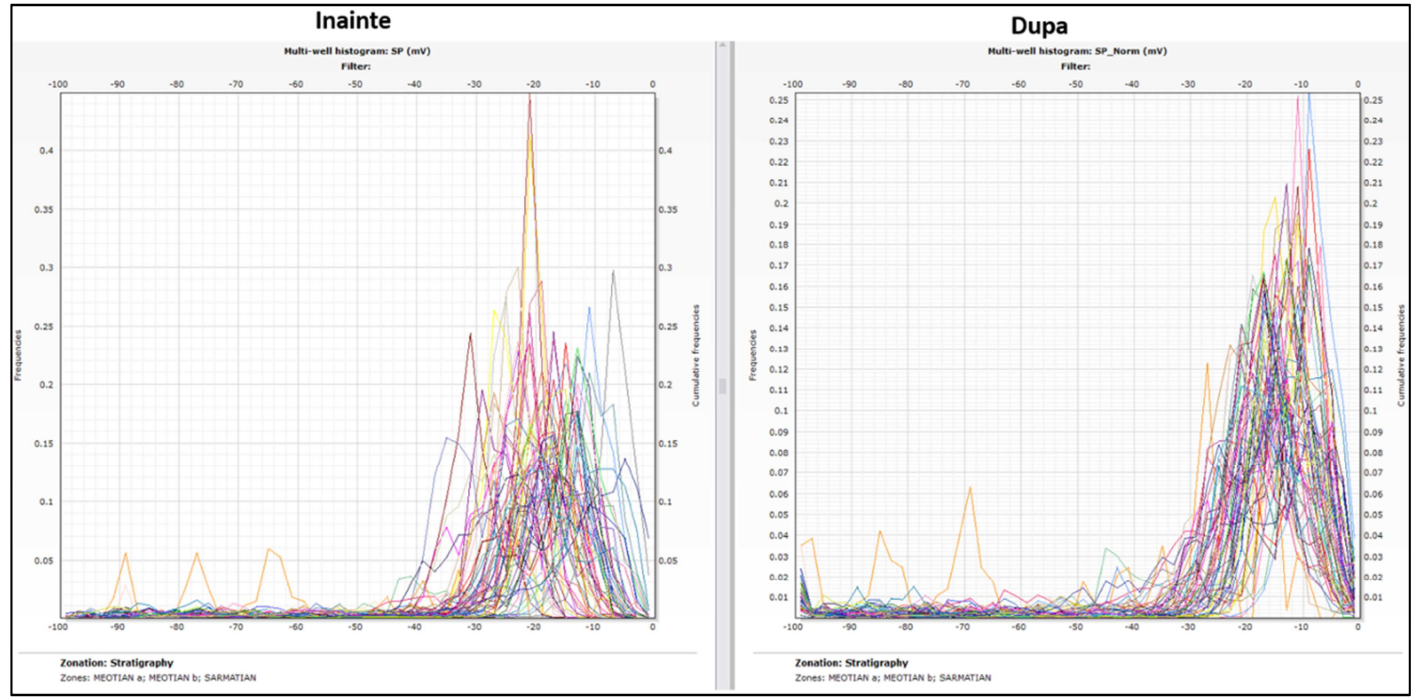

Figure 1. PS histograms, before and after normalisation.

Three lithofacies were separated (sands, silt and shales) in accordance with the structural characteristics and the grain sizes from lithological descriptions from cores.

The ,shale" facies was identified as a non-reservoir rock, and in terms of the quality of the reservoir rock, the „sand" facies was considered the best reservoir rock, followed by the ,silt” facies (Figure 2).

The interpretation diagram of the well logs, the final result of the petrophysical analysis includes the calculated value curves for shale volume, porosity, water saturation, permeability, as well as highlighting with different colours the reservoir intervals (Figure 3). 


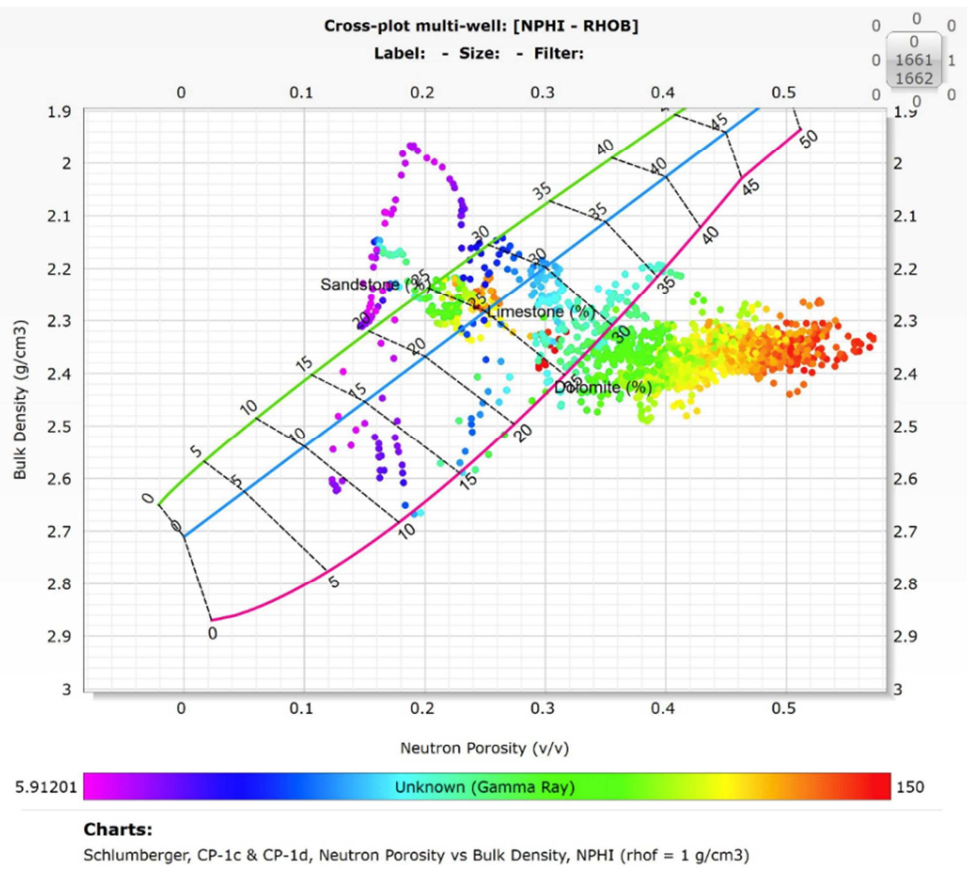

Figure 2. Porosity, Neutron-Density Cross plot, Meotian.

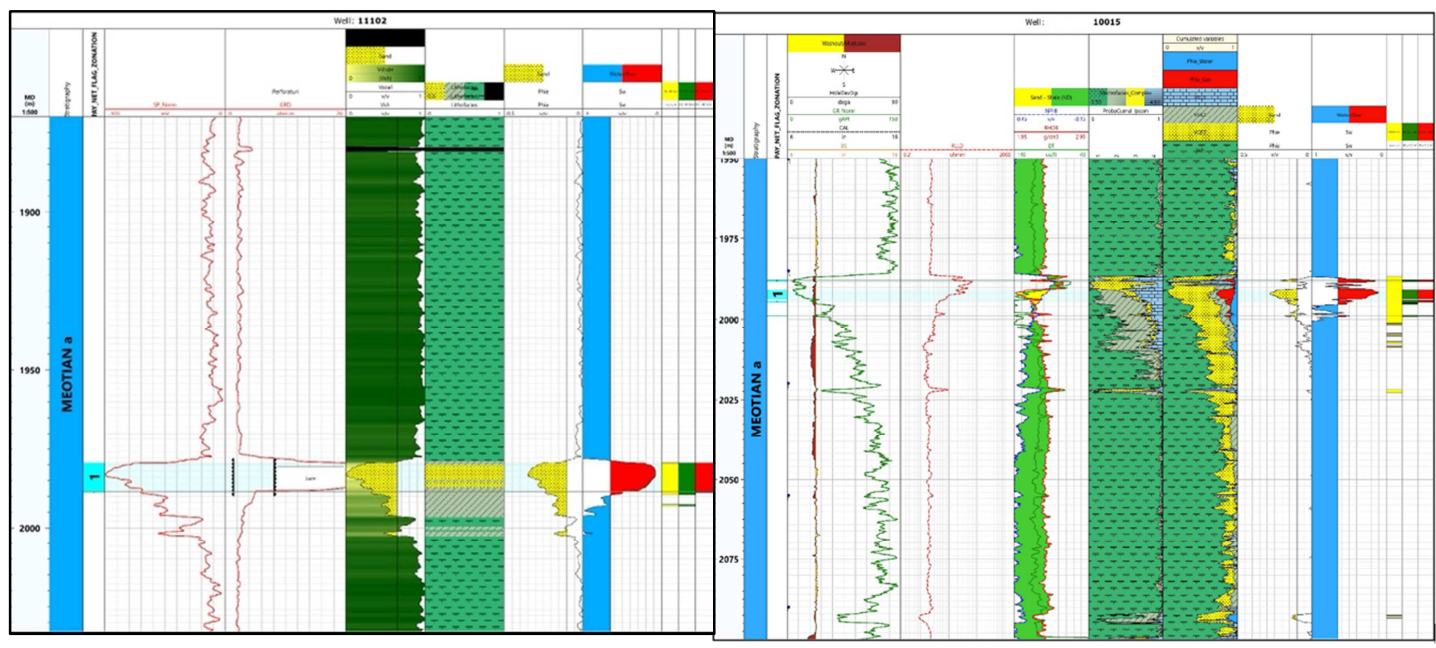

Figure 3. The petrophysical analysis for the electric standard logs.

This paper showed how to use modern technologies in an old reservoir and processing these data in a computerised image of the reservoir using relatively cheap software programs.

\section{RESERVOIR ENGINEERING}

During the extraction phase we had 2 stages. The first one was focused exclusively on gas extraction through 9 wells, which lead to a decrease in pressure by $80 \%$. During this phase the wells had variable flow rates ranging from 67 to 293 thousand Stcm/day for pressures ranging from 100 to 160 bars. 
The second phase focused both on gas extraction, as well as gas storage through 67 wells. During this phase the extraction debits ranged from 20 to 650 thousand Stcm/day for pressures from 40 to 140 bars. while the gas injection debit flows ranged from 40 to 300 thousand Stcm/day, with pressures from 50 to 140 bar.

We have found that in the second stage reservoir pressure increased significantly, by more than 70 bars.

The reservoir pressure and the behaviour during production indicates a gas expansion is the main displacement mechanism, alongside a low influx of water.

The evaluation of the gas flow rate was done by comparing the gas flow in different moments of time, but with the same equipment and static reservoir pressure.

\section{CONCLUSION}

This study was focused on creating a data base that geologists, geophysicist and reservoir engineers can use to improve data integrations. This multidisciplinary analysis, as well as the creation of a neural network model, was created as an alternative instrument of interpolation and prediction for the petrophysical parameters, and was extremely useful in the correct and fast evaluation of the reservoir which lead to a decrease in risks and an increase in the economic value of the reservoir.

By acquiring the data from seismic and from the wells, we proved that our structure has all the necessary components of a reservoir. We have a quality reservoir rock filled with gas, and in the presence of structural and lithostratigraphic traps.

Seismic interpretation supplied the geometry and topography of the reservoir, with the reservoir stratigraphy being defined using data from neutron and density logs.

The reservoir was defined as having a greater than $15 \%$ porosity and a smaller than $45 \%$ volume of shale, while the productive intervals are those having a smaller than $55 \%$ water saturation.

Information about the petroleum systems in the Moesian Platform are relatively rare, so our findings are of extreme importance.

This study generated data regarding the petroleum system of the Miocene structure, at a regional scale, using an integrated approach, data which can be used as an instrument for future exploration and extraction activities.

The lithofacial properties of the reservoir were obtained by reinterpreting the available data.

New zones, favourable to hydrocarbon accumulation, were highlighted. This can be explained with the existence of a depositional canal which was highlighted with a cylindric electrofacies.

In conjunction with well data, logs, cuttings etc., the 3D seismic interpretation lead to a plotting of the distribution of the proprieties for the entire reservoir.

The existence of extremely favourable zones for gas flow (canal deposits) shapes the optimal perimeters for the layout of injection/extraction wells. 
Seeing the results of the study, the author recommends the increase, both of the storage capacity, and an increase in daily gas extraction, by drilling four new wells in the study area. This is preferable to a continuation of the current extraction-injection program.

\section{REFERENCES}

[1] Dinu, C., Motariu, C., and Mocanu, V.I., Hydrocarbon resources of Romania - An overview, in Wessely, G., and Liebl, W., eds., Oil and gas in Alpidic thrustbelts and basins of central and eastern Europe: Special Publication of the European Association of Petroleum Geoscientists [EAGE] No. 5, The Geological Society, London, for the European Association of Geoscientists and Engineers, pp. 23-27, 1996.

[2] Stoica-Negulescu R., Cristea D. Prospecțiune și explorare geofizică - Vol.1 - Metode de Investigare pentru Hidrocarburi și alte Tipuri de Resurse, Editura Vergiliu, București, 2020.

[3] Stoica-Negulescu R., Cristea D., Prospecțiune și explorare geofizică - Vol.2 Interpretarea Geologică a Datelor Seismice, Editura Vergiliu, București, 2021.

[4] Stoica-Negulescu R, - Romanian Oil and Gas from Geophysics to Petroleum Systems, Editura Vergiliu, București, 2015.

[5] Paraschiv D., Geologia Zăcămintelor de hidrocarburi din R.S.Romania, Editura Academiei, București, 1975.

[6] Batistatu, M.V., Investigarea Geologică și Geofizică a Formațiunilor Pre-Miocene din Zona Cutelor Diapire prin Foraje de Mare Adâncime. Universitatea din București, București, Teză de doctorat, 1998.

[7] Slatt Roger M., Stratigraphic Reservoir Characterization for Petroleum Geologists, Geophysicists and Engineers. Editors Elsevier B.V., Olanda, 2006.

[8] Stoicescu, M., Stoianovici D., Teste hidrodinamice în sondă, Editura Universităţii Petrol - Gaze din Ploieşti, 2011. 